\title{
Saving 1968: Thinking with Habermas against Habermas
}

\author{
KEVIN W. GRAY
}

In the penultimate scene of Tom Stoppard's Rock ' $n$ ' Roll, the Czech dissident Jan argues that the purpose of the Velvet Revolution was not to replace one political system with another but instead to change the nature of politics. If the end-result of the revolution was to change from communism to American-style capitalism, then its true purpose was subverted. "All systems are blood brothers," he remarks. "Changing one system for another is not what the Velvet Revolution was for" (Stoppard 99).

In his article "What We Can Learn from the Revolutions of 1989," Richard Wolin identifies two ways in which 1989 has traditionally been understood; either as the triumph of capitalism (and the end of history) or as the triumph of Western-style liberal democracy. ${ }^{1}$ In my paper, I argue that to understand 1989 in either of these ways is to misapprehend the potential of democratic revolutions and to underestimate the importance of the public sphere. Taking Habermas's article "Die nachholende Revolution" as a foil, I contend that in his writing on 1989, Habermas has misunderstood the revolutions that rocked Eastern Europe. Comparing them to his work on the public sphere and the student protest movements in Germany, I argue that the revolutions do not represent the triumph of Western capitalism anymore than they represent the triumph of Western democracy. Calling the events "catch-up revolutions" (which is what a translation of the German would be) is to frame the events as the expansion of modernity and nothing more. Rather, the revolutions show that the revolutionaries in Eastern Europe were 
grappling with the same problem (namely the control of technical subsystems) as the students and revolutionaries of 1968. Viewed in the light of Habermas's writings from the 1960s, we end up better understanding the twin extremes of capitalism and bureaucratic-totalitarianism. Habermas's description of the spirit of 1989 may be correct in light of how post-Communist society developed, but his normative claims about 1989 and the lessons to be learned are flawed.

\section{The Bourgeois Public Sphere}

If there was any text that had a claim to centrality in the student protest movement in Germany in the 1960s, it was Habermas's Structural Transformation of the Public Sphere. Habermas's description of the dangers of technocratic and bureaucratic expansion for attempts to regulate modern capitalist economies through discursive will-formation found instant resonance with the German students.

In the book, Habermas sees three decisive events leading to the creation of the public sphere in early modern Europe. First, the market-demand for information about distant events led to the creation of a system of information exchange (Habermas, The Structural Transformation of the Public Sphere 16). A regular mail service, starting from the middle of the $14^{\text {th }}$ century, was organized by merchants to carry news; towns became important centers for the trade of information. Thus, simultaneously to the organization of stock markets, postal services and the presses instituted a system of regularized communication. The second important event was the change in the nature of the family brought about by the industrial revolution. Activities once relegated to the household economy emerged into the capitalist economy: "economic activity ...

had to be oriented toward a commodity market that had expanded under public direction and 
supervision" (Habermas, The Structural Transformation of the Public Sphere 19). For example, activities connected to mere survival (e.g. the production of food stuffs) became elements of the new capitalist system. ${ }^{2}$ Third, there occurred the growth of the commercial presses. Journals developed out of the simple rules of economics: news itself became a commodity; printed journals developed out of the exchange of private newsletters. ${ }^{3}$ Access to the news of the day was available for purchase in the market, alongside all other commodities.

It was the combination of these three events that lead to the emergence, in the sense of the word intended by Habermas, of a reading public: a public that had an interest in and the wealth necessary to buy journals and to keep abreast of the latest news. ${ }^{4}$ A rapidly expanding parallel system (the nascent capitalist economic system) created a market for information and a supply of ready consumers. ${ }^{5}$ This area, the bourgeois public sphere, came to be conceived as the area of private people coming together against the political authorities themselves.

The bourgeois public sphere brought with it three important changes to the legitimation of political discourses. First, the coffee houses (the original locus of these debates) inverted typical deference to rank and social class, permitting the strength of the best argument to determine consensus. Second, this form of public debate permitted a problematization of areas (e.g. politics) not previously open to discussion. Third, the process that gave rise to public culture meant that it was in principle impossible for the public sphere to become closed-any person, provided they were literate, had access to the necessary materials to participate in public debate. Access to the public sphere became a commodity that could be purchased, comparatively cheaply, in the market place. ${ }^{6}$

The features that allowed this debate to occur would not last for long. By the end of the $19^{\text {th }}$ century, the state had begun to interfere with greater and greater frequency in the affairs of 
commerce. Habermas dates this interference to the end of this first liberal era and to the Great Depression of $1873 .^{7}$ As a result of this economic downturn, all the advanced capitalist countries more or less abandoned the principles of free trade in favour of new forms of protectionism. Furthermore, laissez-faire economics was on the way out. The theory that the capitalist system was naturally self-regulating gradually came to be rejected in favour of the explanation that unregulated capitalism could ensure fair competition only under exceptional circumstances. ${ }^{8}$ Agitation by the lower-classes forced governments to intervene more often and more aggressively in the economic sphere. This increased intervention lead to increased contractual arrangements between the state and private individuals, further blurring the separation between state and public sphere.

This was not the only way the public sphere changed. At the close of the $18^{\text {th }}$ century, the public, as defined by the limits of the public sphere, expanded beyond the educated classes to include retailers, and other members of the petty bourgeoisie. This was enabled by a decrease in the price of books and periodicals, and an increase in the number of book clubs, societies for popular education, etc.. The increased economic potential of the public sphere allowed for the commodification of culture. In these cases, the choices of what reading materials were relevant—what books should be read, what art discussed—passed beyond the control of the group's membership. A class of experts, professors, teachers, etc., developed who were responsible for instructing the petty bourgeoisie on what culture to consume. Eventually these experts became less dominant, and book clubs formed, in the modern sense of the word, wherein much of the choices surrounding cultural consumption were made by corporations. ${ }^{9}$ This expansion had the effect of levelling all distinctions between novel, entertainment, human 
interest story and advertising. The further development of media technologies in the $19^{\text {th }}$ and $20^{\text {th }}$ centuries changed the role of media in the public sphere-radio, film and television made the consumption of media a private affair, separate from the world of the discussion of belleslettres. $^{10}$

The original argument was that the public sphere was supposed to keep the press free of interference precisely because it was held in the hands of private individuals. Instead, the fact that private enterprises became increasingly profit-oriented turned the news into a commercialized, concentrated commodity (Habermas, The Structural Transformation of the Public Sphere 182). At first, literary journals had been published with little or no regard to profit; many were the pet projects of individuals and were often loss-sustaining. Political journals had been attached to parties or viewpoints of prominent individuals: each political journal was forced to justify its continued existence in the sphere of ideas. With commercialization, however, the economic footing of the journal was put on more secure ground. But, this meant that the editorial section and the advertising section were no longer independent-in fact, the new interdependence subordinated the editor to the publisher. Habermas argues that, "since the 1870s the tendency has become manifest...the publisher appoints editors in the expectation that they will do as they are told in the private interest of a profit-oriented enterprise" (The Structural Transformation of the Public Sphere 186).

In this way, the public sphere became an area for advertising, and had an effect on the activities of private individuals; Habermas refers to this as the "refeudalization of the public sphere," the domination of large corporations over what material is available for cultural consumption (Habermas, The Structural Transformation of the Public Sphere 195).$^{11}$ The growth of large corporations operating in the media of the public sphere allowed advertisers and 
business interests to encroach on the public sphere. It distorted the topics that were open to discussion in the public sphere as media began to colonize culture. Thus, we can say that the public sphere is created by, sustained by, and threatened by the capitalist economic system. It neither emerges independently, nor continues to exist without being threatened by outside forces.

\section{The Role of the University in an Advanced Capitalist Society}

The expansion of the university system in post-war Germany created both greater access to knowledge and greater social unrest. Open for the first time to the children of the non-elite, the universities became an area where politically-informed, often subversive discourse, could occur. Students became increasingly aware that they were being exposed only to technical knowledge and not being groomed, as in previous generations, for leadership roles; student leaders in turn protested the fact that the universities had failed to reform after the Second World War and feared that the university might soon cease to be a institution that allowed for the effective control of the growth of technological knowledge and exploitation, and hence organization that might temper the growth of self-controlling subsystems. The idea that the public sphere might, through discursive principles, mediate the economic and bureaucratic subsystems inherent to $20^{\text {th }}$ century late-capitalist society, and that it could well be failing in Germany, captured the student movement in Germany and informed Habermas's writings on 1968.

In his essay "The Movement in Germany," Habermas argues that the student organizations' actions must be partially understood as an attempt to avoid integration into "the all-pervasive system of mass media" (32). ${ }^{12}$ Habermas elaborates on this point, arguing that universities must transmit technically exploitable knowledge-that is, the dissemination of 
knowledge must be such that knowledge might be harnessed as techne which itself can in turn be used by succeeding generations. Contra the positivist attitude, however, the progression and development of science must nonetheless be harnessed and controlled by the public sphere. ${ }^{13}$ Part of the task in modern society is to find a way for the specialized discourses of modern scientific subfields to speak to one another. Universities represent a place where a public sphere can be realized, where self-reflection and public discourse are possible.

Problematically however, the student demonstrations lead to a cycle of tit-for-tat revenge action: demonstrations are directed against any provocation; these immediately provoke a harsh counter-reaction from the other side. Seen as part of Habermas's research program, this creates a situation where there is no possibility of discourse within the public sphere. The impossibility of discourse, however, may not be beyond the wishes of the most radical students, who intend to destroy, rather than reform, politics in Germany. Habermas writes: "The devaluation of the political sphere as an area of purposive-rational action is connected with another intention," namely, attacking all forms of authority structures within existing society, in an attempt not to change, but to destroy it (Towards a Rational Society 32).

Habermas rejects three of the dominant goals of the student protests: anti-imperialism, neo-anarchism, and cultural revolution. He instead argues that they have become fetishized objects akin to the very cultural objects the student movement struggles against.

The three interpretations that determine the self-understanding of the protest movement in its militant form have rational elements. But as a whole they coincide so little with empirically supported judgments of reality that some of their contents have become idées fixes. Especially amongst actionist groups, syndromes of this sort have already been terminologically rigidified (Towards a Rational Society 40).

The student movement, having become indoctrinated with these ideas, has failed to notice the rapid expansion of democracy in some existing structures of society. This is not to say that the 
universities have become completely free-clearly this is not the case. However, blind statements of the sort that society must be entirely destroyed, rather than modified, have no place in Habermas's social theory. As the protest movement originated in the universities, it remains clear that reforming the universities must remain the primary goal. Social change must revolve around the democratization of decision-making, and include an end to bureaucratic domination. The structure of the universities must be changed to allow for communicative flows between students and administration.

In line with Habermas's reading of events, he has three central elements to his political program: 1) instruction at the universities should be modified such that better career preparation is available outside traditional modes of study; 2) the university should give up its apolitical selfunderstanding in order to take control over the ways in which new technologies are used; 3) the scientific system of research, properly directed, should influence the positive development of the education system.

The task is to find a way to encourage specialized disciplines to talk to each other. The task of philosophy becomes to take on the role of critical interpreter, existing not as a fundamental science, but to allow various systems to communicate with each other: "philosophy ... can legitimately go beyond the area reserved to it by assuming the role of interpreter between one specialized narrow-mindedness and another" (Habermas, Towards a Rational Society 8). In this way, the universities represent a place where a public sphere can be realized, where selfreflection and public discourse are possible.

I believe it possible to advocate this thesis because the only principle by which political discussions at the universities can be legitimated is the same principle that defines the democratic form of decision-making, namely: rationalizing decisions in such a way that 
they can be made dependent on a consensus arrived at through discussion free from domination (Towards a Rational Study 10).

For this reason, we can speak of a need for the students to have a say in the running of the university, a need that should be defended through demonstrating the important relationship between knowledge at the university and the critical impulse (Towards a Rational Study 11).

Habermas' desire to find a place for the students in the university administration is informed by his early work on the public sphere. Students protested the strictly prescribed courses of study, state power structures, and the relationship between the university and the state because they feel that to do otherwise would be to allow themselves to be incorporated into the system of mass media. Because the public sphere has been so thoroughly corporatized, public discourse has been rendered impossible. The conditions that Habermas diagnosed at the end of the $19^{\text {th }}$ century in the public sphere have been reproduced on German campuses.

\section{The Central Claim of Die nachholende Revolution}

In Between Facts and Norms, Habermas addresses the Enlightenment ideas embedded in the French Revolution of 1789 , arguing that the ideals of that revolution represent the end state of political development, combining the protections of the constitutional state, respect for the law, and constitutional patriotism. The revolutions of 1989, on that telling, represent nothing more than a necessary correction and return to the ideas of two centuries earlier. ${ }^{14}$ The importance of the revolutions is merely to catch-up with the West, and implement the ideas contained in the constitutional revolutions at the end of the $18^{\text {th }}$ century. With this belief is mind, Habermas is free to make the controversial statement that there is "a peculiar characteristic of 
this revolution [i.e. 1989], namely its total lack of ideas that are either innovative or orientated towards the future" ("What does Socialism Mean Today?" 5).

From the perspective of a social philosophy solely concerned with the question of the rights of the citizen, this interpretation might be correct: the only rights that were now guaranteed are those of the French Revolution that were first taken away by the Revolution of 1917. However, it is unclear that this entails the death of the socialist project, or its radical transformation, as Habermas claims. The development of socialist bureaucracy in Eastern Europe shows that the resolution of difficulties related to the establishment of effective systems of control cannot be left to the bureaucracy. ${ }^{15}$ The conditions of possible communication become central to the establishment of democratic processes and to the legitimation of government decisions.

The communicative conditions necessary to the establishment of justified confidence in the institutions of rational self-organization of a society of free and equal citizens become central precisely when one adheres to the critique of naturalized and unlegitimated forms of power (Habermas, "What does Socialism Mean Today?" 15).

In other words, restraining conditions need to be imposed to prevent the unadulterated exercise of power over a population, the exercise of which might threaten to overwhelm the structures that give rise to rational discourse.

The idea then is that democratic processes of rationality are supposed to be codified so that the growth of bureaucratic structures can be prevented. ${ }^{16}$ However, Habermas wants to argue that this means that:

[T] he revolutionary changes taking place before our eyes teach us an unambiguous lesson: complex societies are unable to reproduce themselves if they do not leave the logic of an economy that regulates itself through the market intact. Modern societies separate out an economic system regulated by the medium of money in the same way as an administrative system; the two systems are on the same level, and however their 
various functions complement one another, neither may be subordinated to the other ("What does Socialism Mean Today?" 16-17).

The only question that remains is one of tinkering with the machinery of a market economy that remains nonetheless inured to the suffering and socially negative side effects it creates: "A welfare-state compromise that has established itself in the very structures of society now forms the basis from which any politics here has to start" (Habermas, "What does Socialism Mean Today?" 17). And thus, the famous quote: "With the bankruptcy of state socialism, this [welfarestate capitalism] is the eye of the needle through which everything must pass" ("What does Socialism Mean Today?" 21). It is this argument, that economic subsystems and government bureaucracy must remain separated (and at most what must occur is redistribution), as in the Western model, that I propose to challenge.

\section{The Scientization of Politics}

In an important essay from the same period as his writings on the student protests, "The Scientization of Politics and Public Opinion," Habermas examines the ways in which technicalrational reason had come to dominate the sphere of political discourse. His central argument is that, while the transition to a newer form of bureaucratic domination is not complete, it represents a new form of social organization. ${ }^{17}$ In this context, the scientization of public opinion refers to the change that occurs as political leadership becomes less important, and public officials take on the function of ensuring that the technical-rational values of science and industry dictate government policy.

Habermas turns to Max Weber to explain the pathologies of modern economies. Weber contended that the growth of bureaucracy was a reaction to the need for normative validation in 
societies where an over-arching religious worldview has largely disappeared. In these cases, bureaucracy and technocracy act as substitute systems of values. Weber had argued that there were three distinctive stages through which public-government relations pass under capitalist development: the growth of the bureaucratic state, the installation of decisionism, and finally the development of technocracy. The first stage refers to the institution of a system of bureaucrats who are charged with implementing government decisions, but where the government, nevertheless, retains the ability to dictate governmental goals. The second stage, decisionism, is a transitory state of affairs, occurring when the bureaucracy begins to take on more and more control of day-to-day decision-making; decisions are made through a process of systems analysis (and the application of decision theory) designed to optimize the results of processes set in motion by public decisions. Decisionistic societies rapidly develop into the third stage, wherein the procedures of systems analysis instead settle the solutions to questions that would have previously been open to public debate. Soon, the original model of the relationship between expertise and political practice is reversed; the bureaucratic government that coincided with early state capitalism (as it existed in Western European nations at the end of the $19^{\text {th }}$ century and the beginning of the $20^{\text {th }}$ ) fades into technocracy.

Under Weber's technocratic description of government, the prerogative of technocrats to make value decisions is formalized, and the determining role of political practice (decision procedures such as debate, elections, etc.) is usurped. In the late-capitalist state, the politician in the technical state is left with nothing but a fictitious decision-making power. In the final instance, the political will of the people is supplanted by the objective exigencies of science and labour. 
Habermas opposed Weber not on empirical, but on normative grounds. These models, Habermas argues, are not a priori valid at certain stages of technological development. The challenge for contemporary critical theory is to retake control of decisions from scientific systems. There is no reason why, in principle, the supposedly valueless decisions made by the technocracy cannot be challenged: the growth of excessive instrumentality can be checked through the development of democratic systems of control.

Drawing on Weber's diagnosis of the rise of decisionism in modern society, Habermas claims that technical domination accompanies a loss in lifeworld values that might militate otherwise against the growth of social subsystems. His central argument is that, while the transition to technocratic domination is not complete, it represents a new form of social organization that must be taken seriously by social scientists. He writes: "The scientization of politics is not yet a reality, but it is a real tendency for which there is evidence: the scope of research under government contract and the extent of scientific consultation to public services are primary examples" (Habermas, Towards a Rational Society 62). The growth of both is evidence of a change that occurs when political leadership (and political decision-making) becomes less important, and public officials take on the function of ensuring that the technicalrational values of science and industry dictate government policy, rather than choosing the necessary direction of government policy through democratic means. In other words, system imperatives begin to drive decisions that should otherwise be made through democratic means of will formation.

Weber had argued that the growing bureaucratization of society brought with it an equal pressure to find new normative sources of justification. As capitalism advanced, it brought with it, alongside the death of religious and the functional differentiation of the modern world, a 
concomitant demise of traditional legitimations; as government bureaucracy became more entrenched, more tied to the stabilization of the conditions of economic reproduction, and political debate became less robust, the normative strength of government needed to be preserved in a different way. Government was too deeply coupled to economic activity to be capable of separating out its normative foundations from those of the economy. New values needed to be injected into political debate.

\section{Concluding Remarks}

I want in my conclusion to challenge the claims of Die nachholende Revolution. Habermas claims that the problem of the relationship between bureaucracy and economics has been solved in favour of the independence of the latter; all that remains is to tinker with economics to assure the functioning of the welfare state. However, this would seem to contradict what Habermas said about the public sphere, about Weber in the 1960s, and in his diagnosis of the student protest movement.

Reconsidering that conclusion in light of Habermas' earlier writings, we see that Habermas has devalued the role of the public sphere while instead emphasizing the libratory role of the capitalist economy. As I highlighted in my earlier discussions, Habermas interpreted the student protests of 1968, particularly in Germany, in three ways. First, there was the desire to seize control of the media such that no one company (Axel Springer AG in the German case) might control the public sphere and allow discourse to become monopolized. Second, the students' goal was to democratize the universities such that technological program of study did not yield to the corporate university. Third, the students wanted to split the bureaucracy of 
technocracy (whether in liberal democracy or elsewhere) from the control mechanisms of society.

Understanding the Revolutions of 1989 merely as the triumph of market socialism (which they may ultimately have been, unfortunately or otherwise) would be to misunderstand the actual impulse of the protestors. Recalling Jan's words, the goal of the revolutionaries in 1989 was not to introduce capitalism, but to end another system. Every one of the students' original complaints about the bureaucratization and the corporatization of the public sphere is as valid today in the West as they were in the 1980s in the East. To see them therefore as merely catch-up revolutions is to fail to understand that bureaucracy and technocracy represent twin extremes, and that only a reformulation of the public sphere can offer a way forward.

Habermas' discussion of Weber's discussion of the development of bureaucracy helps to guide us here. These revolutions serve to remind us of the danger of the refeudalization of the public sphere. Only if Habermas believes today, unlike in 1968, that the public sphere was a natural state of affairs (a decidedly un-Marxist position), can we be sure that the economy does not need regulation to preserve the independence of the public sphere. In fact, we see in both cases the tendency of unchecked media (controlled either by economic or bureaucratic forces) to colonize the public sphere. This as well must be the lesson of 1989. The free-market offered us as much to fear in the $19^{\text {th }}$ century as it does today. Seeing only technocracy is to turn away from the original diagnosis. 


\begin{abstract}
Notes
${ }^{1}$ The article is published in The Frankfurt School Revisited and Other Essays. Wolin here is referencing Fukuyama's The End of History and the Last Man, and Habermas's Die nachholende Revolution (published in English as "What Does Socialism Mean Today?").

2 This is the standard Marxist description of the evolution of the family. Properly speaking, even the meaning of the word economic began to change. Whereas once it referred merely to activities supervised by the head of the household, it began in the $17^{\text {th }}$ century to take on its modern meaning (Habermas, The Structural Transformation of the Public Sphere 20).

${ }^{3}$ Printed journals "developed out of the same bureaus of correspondence that already handled hand-written newsletters. Each item of information contained in a letter had its price; it was therefore natural to increase the profits by selling to more people" (Habermas, The Structural Transformation of the Public Sphere 21).

${ }^{4}$ This public expanded rapidly to include not only merchants and traders, but all others, such as factory owners, manufacturers, etc., who might need similar information to plan their businesses.

${ }^{5}$ Habermas argues that because this new area of commerce had developed initially free of state interference (contrary to the organization of the old feudal system), an area developed between state regulation and the private initiative of individuals. This change:
\end{abstract}

[T] urned the reproduction of life into something transcending the confines of private domestic authority and becoming a subject of public interest, that zone of continuous administrative contact became 'critical' also in the sense that it provoked the critical judgment of a public making use of its reason (The Structural Transformation of the Public Sphere 24).

Habermas argues that this situation (wherein a public realm is created to mediate between the emergent claims of private individuals against the state) created a need for a better informed public. By the end of the $17^{\text {th }}$-century, alongside the usual informational content of journals were published periodicals featuring pedagogical instruction as well as criticism and review. Amongst these articles were published the opinions of professors, doctors, etc. who wrote articles for the betterment of the populace.

${ }^{6}$ Habermas writes that the market provides every citizen access, in principle, to the public sphere:

Readers, listeners, and spectators could avail themselves via the market of the objects that were subject to discussion. The issues discussed became 'general' not merely in their significance, but also in their accessibility: everyone had to be able to participate (The Structural Transformation of the Public Sphere 37). 
7 The depression was brought on by banking and credit crises in the United States and in Continental Europe, and worsened by poor harvest in Britain, which in turn began to restrict the import of foreign goods.

${ }^{8}$ The processes of concentration and crisis showed that commerce was not exchanged among equals, as supposed, but rather, that commerce took place within a society that was composed of a nexus of coercive constraints (Habermas, The Structural Transformation of the Public Sphere 144).

${ }^{9}$ The mass press was based on the commercialization of the participation in the public sphere on the part of broad strata designed predominantly to give the masses in general access to the public sphere. This expanded public sphere, however, lost its political character to the extent that the means of 'psychological facilitation' could become an end in itself for a commercially fostered consumer attitude. In the case of the early penny press it could already be observed how it paid for the maximization of its sales with the depoliticization of its content - by eliminating political news and political editorials on such moral topics as intemperance and gambling (Habermas, The Structural Transformation of the Public Sphere 169). Alongside this was an increase in so-called yellow journalism of the 1880s, with the introduction of cartoons, human-interest stories, etc. (It was named yellow journalism because of yellow color of the comics. Eventually the term took on its modern meaning.) At the same time as the public sphere expanded, the number of novels bought or even read in the average household plunged precipitously.

${ }^{10}$ Habermas theorizes this as a shift in the principle of publicity:

On the one hand, to the extent that the press became commercialized, the threshold between the circulation of a commodity and the exchange of communications among the members of a public was levelled; within the private domain the clear line separating the public sphere from the private became blurred. On the other hand, however, to the extent that only certain political guarantees could safeguard the continued independence of its institutions, the public sphere ceased altogether to be exclusively a part of the private domain (The Structural Transformation of the Public Sphere 181).

The principle of publicity essentially states that all arguments must be open to public discussion, and all actions and laws must be made known to the public so that such dialogue can occur.

${ }^{11}$ Habermas argues that the role played by representative symbols, rather than arguments, in the refeudalized public sphere mimics the role of the public sphere as a place for staged publicness during feudalism.

12 This essay is published in the book Towards a Rational Society, along with the text "The Scientization of Politics and Public Opinion." 
${ }^{13}$ Habermas writes:

It makes a difference whether we are discussing standards that, as in science, establish the framework for descriptive statements or standards that are rules of communicative action. But both are cases of the rationalization of a choice in the medium of unconstrained discussion. In very rare cases practical questions are decided in this rational form. But there is one form of political decision-making according to which all decisions are supposed to be made equally dependent on a consensus arrived at in discussion free from domination-the democratic form. Here the principle of public discourse is supposed to eliminate all forces other than that of the better argument, and majority decisions are held to be only a substitute for the uncompelled consensus that would finally result if discussion did not always have to be broken off owing to the need for a decision (Towards a Rational Society 7).

${ }^{14}$ In an interview with Adam Michnik, the Solidarity leader, Habermas remarks that he did not think Stalinism or Eastern European Marxism were important, as neither contained important new ideas or criticisms (Habermas and Michnik, 54).

15 Habermas himself clearly believes as much. The rapid development of technology and increase in social complexity in the $20^{\text {th }}$ century have made socialism as project at best an abstract ideal that must be substantially revised. He has written: "Faced as we are with a higher level of social complexity, we must submit the normative implications attached to this nineteenth-century theoretical formulation to a process of radical abstraction" (The Structural Transformation of the Public Sphere 15).

${ }^{16}$ Habermas writes:

The presupposition of efficacy touches upon the fundamental materialist question of how a differentiated social system that lacks both summit and centre might still organize itself, once one can no longer imagine the 'self' of self-organization embodied in the form of macro-subjects such as the social classes of theories of class, or the people of popular sovereignty. The point of conceiving mutually supportive relations abstractly is to separate the symmetries of mutual recognition, presupposed by communicative action, that make the autonomy and individualization of socialized subjects possible in the first place, from the concrete ethical practice of naturalized forms of behaviour, and generalize them into the reflexive forms of agreement and compromise whilst simultaneously safeguarding them through legal institutionalization. The 'self' of this self-organizing society then disappears into the subjectless forms of communication that regulate the flow of the discursive formation of public opinion and political will, such that one can continue to presuppose the rationality of their fallible results. By dissolving into intersubjectivity, popular sovereignty is made anonymous, and then allowed to retreat into the democratic process and the legitimate communicative presuppositions of its implementation. (The Structural Transformation of the Public Sphere 15-16). 
${ }^{17}$ He writes:

The scientization of politics is not yet a reality, but it is a real tendency for which there is evidence: the scope of research under government contract and the extent of scientific consultation to public services are primary examples (Habermas, Towards a Rational Society 62).

\section{Works Cited}

Fukuyama, Francis. The End of History and the Last Man. New York: Free Press. 1992.

Habermas, Jürgen. Between Facts and Norms. Cambridge: MIT Press. 1992.

-. "What does Socialism Mean Today? The Rectifying Revolution and the Need for New Thinking on the Left." New Left Review, no. 183 (1990): 3-21.

- The Structural Transformation of the Public Sphere: An Inquiry into a Category of Bourgeois Society. Cambridge: MIT Press. 1991.

—. Towards a Rational Society. Boston: Beacon. 1970.

Habermas, Jürgen and Adam Michnick. "Overcoming the Past." New Left Review, no. 203 (1994): 3-16.

Stoppard, Tom. Rock 'n’ Roll. London: Faber \& Faber. 2006.

Wolin, Richard. The Frankfurt School Revisited and Other Essays on Politics and Society. New York: Taylor and Francis. 2006. 